\title{
PERSEPSI MAHASISWA PENDIDIKAN KEPELATIHAN OLAHRAGA FPOK UPI MENGENAI PENDIDIKAN GIZI UNTUK MENCEGAH KECENDERUNGAN EATING DISORDER PADA ATLET
}

\author{
Cica Yulia ${ }^{1)}$, Pipit Pitriani2), Rita Patriasih" ${ }^{1)}$ \\ ${ }^{1)}$ Program Studi Pendidikan Tata Boga, PKK, FPTK UPI \\ ${ }^{2)}$ Program Studi Kepelatihan Olahraga, FPOK, UPI \\ Jalan Dr. Setiabudhi No.207 Bandung. 40154 \\ e-mail: cicayulia@upi.edu
}

\begin{abstract}
Abstrak. Kondisi fisik seorang Atlet sangat mempengaruhi stamina ketika mereka bertanding. Indikator kondisi fisik yang prima dari seorang Atlet adalah status gizi dan status kesehatan. Salah satu masalah kesehatan yang sering di hadapi oleh para Atlet adalah Eating Disorder atau penyimpangan perilaku makan. Tujuan dari penelitian ini adalah menjaring persepsi mahasiswa Pendidikan Kepelatihan Olahraga FPOK UPI yang berprofesi sebagai atlet mengenai pendidikan gizi untuk mencegah kecenderungan eating disorder. Metode Deskriptif digunakan dalam penelitian ini dengan pendekatan cross-sectional desain, Teknik pengumpulan data menggunakan kuesioner. Hasil penelitian menunjukkan bahwa responden mempunyai persepsi kuat bahwa pendidikan gizi sangat penting dalam mencegah kecenderungan Eating Disorder pada atlet. Sebagian besar responden setuju bahwa tempat yang paling tepat untuk menyampaikan pendidikan gizi bagi para atlet adalah di kampus dan klub olahraga. Setengah dari responden memberikan persepsi bahwa bentuk kegiatan yang paling tepat dalam menyampaikan pendidikan gizi bagi atlet adalah penyuluhan secara berkala, dengan menggunakan metode gabungan dari diskusi, demontrasi dan simulasi, dan durasi yang dianggap tepat selama 60 menit, serta media yg tepat adalah audio visual.
\end{abstract}

Kata Kunci : atlet, pendidikan gizi, eating disorder

\begin{abstract}
Abtract. Physical conditions greatly affect an athlete's stamina, which depends on the nutritional and health statuses. One of the health problems that is often encountered by athletes is Eating Disorder or abnormal eating behavior. The purpose of this study is to apprehend the perceptions of the athletes in Sport Coaching Education Departement FPOK UPI concerning nutrition education to prevent eating disorder tendencies. This study used a cross-sectional design, in which data collected using questionnaire. The results show the respondents' strong perception of the importance of nutrition education preventing eating disorder tendencies. Most respondents agreed that campus and sport club are right places where nutrition education can be delivered. Half of the respondents accepted that the most appropriate form of action in delivering nutrition education is periodical counseling, incorporating discussions, demonstrations, and simulation methods, within 60 minutes and presented using audio-visual media.
\end{abstract}

Keywords: athletes, nutrition education, eating disorder. 


\section{PENDAHULUAN}

Prestasi seorang Atlet di pengaruhi oleh banyak faktor diantaranya faktor psikologis seperti motivasi, kepercayaan diri, konsentrasi, kecemasan, emosi dan berfikir positif. Faktor lain yang turut berkontribusi terhadap prestasi seorang Atlet ialah faktor fisik. Kondisi fisik seorang Atlet sangat mempengaruhi stamina ketika mereka bertanding. Indikator kondisi fisik yang prima dari seorang Atlet adalah status gizi dan status kesehatan. Status gizi merupakan cerminan dari terpenuhinya zat-zat gizi yang dibutuhkan dalam tubuh. Status gizi yang baik di harapkan mampu memelihara stamina para Atlet. Penggalih \& Huriyati (2007) melakukan penelitian pada Atlet di Persatuan Sepak Bola Pasuruan, hasil penelitiannya membuktikan bahwa status gizi seorang Atlet yang di ukur melaui Indeks Masa Tubuh (IMT) berkorelasi terhadap daya tahan (endurance) para Atlet.

Status kesehatan seorang Atlet turut berkontribusi terhadap pencapaian prestasi seorang Atlet. Status kesehatan memiliki hubungan yang erat terhadap status gizi seseorang, karena dengan tubuh yang sehat, semua proses yang berlangsung di dalam tubuh akan bekerja maksimal. Seperti pada proses metabolisme zat gizi dalam tubuh, tubuh yang sehat dapat melakukan metabolisme zat gizi yang baik sehingga zat gizi dapat terserap dengan maksimal, tetapi ketika status kesehatan sedang dalam kondisi yang kurang sehat atau terjadi infeksi, organ pencernaan tidak dapat melakukan metabolisme dengan sempurna, sehingga penyerapan zat gizi pun akan terganggu. Salah satu masalah kesehatan yang sering di hadapi oleh para Atlet adalah Eating Disorder atau penyimpangan perilaku makan merupakan suatu kondisi dimana seseorang membatasi asupan makanan dengan tujuan agar berat badan berkurang dan tidak bertambah.

Kasus Eating Disorder banyak di jumpai di negara-negara maju seperti di Amerika, Eropa dan Australia, terutama pada seorang wanita. Kasus Eating Disorder pada umumnya terjadi pada perempuan yang memiliki profesi public entertainer seperti artis, model, penari, penari balet dan masih banyak profesi lain yang mementingkan proporsi tubuh yang ideal bahkan menuntut pekerjanya untuk berbadan kurus. Seiring dengan perkembangan jaman dan tuntunan berbagai profesi, pada saat ini kasus Eating Disorder tidak hanya di jumpai pada wanita 
dengan profesi public entertainer tetapi juga menimpa para kaum lelaki. Berdasarkan hasil penelitian Borgen \& Torstveit (2004) di Norwegia, dari total responden 1620 orang Atlet dan 1696 orang non Atlet, di temukan 13,5\% Atlet memiliki tanda-tanda klinis menderita Eating Disorder. Penelitian lain tentang Eating Disorder yang di lakukan di Indonesia oleh Saputri dan Dieny (2012) pada 65 orang Atlet putri di PUSDIKLAT Ragunan Jakarta menemukan hasil bahwa 23,1\% dari responden penelitian mengalami Bulimia yang termasuk pada salah satu jenis Eating Disorder.

Eating Disorder pada Atlet seharusnya tidak terjadi apabila mereka memiliki pengetahuan tentang gizi yang baik, sehingga dengan pengetahuan gizi yang baik para Atlet mengetahui kebutuhan zat gizi yang di perlukan oleh tubuhnya sesuai dengan energi yang mereka keluarkan untuk aktifitas fisik tertentu, sebagai contoh Atlet sepak bola memerlukan energi yang berbeda dengan Atlet anggar atau Atlet catur. Pengetahuan gizi yang baik dapat mempengaruhi perilaku gizi seorang Atlet. Pengetahuan gizi seorang Atlet di Iran berkorelasi positif dan signifikan terhadap perilaku gizi seorang Atlet laki-laki dan Atlet perempuan dengan koefisien korelasi masing-masing $\mathrm{r}=0.424, \mathrm{p} \leq 0.01$ dan $\mathrm{r}=$ 0.422, $\mathrm{p} \leq 0.01$ (Azizi, et al : 2010).

Salah satu Program Studi di Universitas Pendidikan Indonesia yang memiliki mahasiswa dan berprofesi sebagai Atlet adalah program studi Pendidikan Kepelatihan Olahraga (PKO), Fakultas Pendidikan Olahraga dan Kesehatan Program Studi PKO mempunyai visi :

"Menghasilkan tenaga Kependidikan dibidang Kepelatihan Olahraga yang berkepribadian sesuai dengan budaya bangsa, agama, serta mengembangkan ilmu pengetahuan dan teknologi yang berkembang di masyarakat untuk menjawab berbagai tantangan dalam kehidupan modern”. Sesuai dengan visi di atas: maka salah satu tujuan program studi pendidikan kepelatihan olahraga adalah: "1. Menyiapkan guru pendidikan jasmani/olahraga yang profesional di sekolah formal dan non formal dan 2) Menyiapkan tenaga pelatih profesional di sekolah dan luar sekolah." 
Berdasarkan salah satu tujuan tersebut di atas, mahasiswa Prodi PKO, FPOK, UPI selain di siapkan untuk jadi guru, mereka juga di siapkan untuk menjadi seorang pelatih profesional di sekolah dan di luar sekolah dalam bidang olahraga. Untuk tujuan tersebut, mahasiswa menempuh berbagai perkuliahan dan mengikuti unit kegiatan olahraga sesuai dengan bakat dan minat yang mereka inginkan. Banyak mahasiswa Prodi PKO yang telah berprofesi menjadi Atlet sebelum mereka menjadi mahasiswa. Sebagai seorang Atlet, tentunya mereka di tuntut untuk memberikan prestasi yang terbaik. Pada beberapa cabang olahraga ada tuntutan para Atlet harus dapat mempertahankan berat badan idealnya, agar mereka dapat tergolong pada salah satu kelas tertentu. Untuk dapat mempertahankan berat badan ideal, banyak cara yang di tempuh oleh para Atlet tersebut, dari praktek diet yang benar hingga pada praktek diet yang dinilai salah.

Penelitian Saputri dan Dieny (2012) pada 65 orang Atlet putri di PUSDIKLAT Ragunan Jakarta menemukan hasil bahwa 23,1\% dari responden penelitian mengalami Bulimia yang termasuk pada salah satu jenis Eating Disorder. Bulimia merupakan suatu Sindrom dimana seseorang makan banyak, tetapi setelah itu mereka berusaha untuk mengeluarkannya kembali, sehingga mereka beranggapan dengan memuntahkan makanan tersebut, berat badan mereka akan tetap stabil. Melihat permasalahan tersebut,tujuan dari penelitian ini adalah untuk mengetahui persepsi mahasiswa mengenai pendidikan gizi untuk mencegah kecenderungan eating disorder pada atlet. penelitian ini di harapkan dapat menjadi data awal dalam menentukan model pendidikan gizi bagi para mahasiswa pendidikan kepelatihan olahraga, FPOK, UPI yang juga berprofesi sebagai Atlet.

\section{METODE}

Metode Deskriptif digunakan dalam penelitian ini dengan pendekatan crosssectional desain, Teknik pengumpulan data menggunakan kuesioner. Populasi dalam penelitian ini adalah seluruh Mahasiswa Jurusan Pendidikan Kepelatihan Olahraga yang sedang menempuh mata kuliah ilmu gizi olahraga. Penetuan responden penelitian menggunakan purposive sampling, dengan ketentuan mahasiswa yang menjadi responden dalam penelitian ini adalah mahasiswa yang berprofesi sebagai atlet berjumlah. Waktu Pengambilan data di lakukan pada 
bulan Februari 2014. Tempat Penelitian di lakukan di Jurusan Pendidikan Kepelatihan Olahraga, Fakultas Pendidikan Olahraga dan Kesehatan, Universitas Pendidikan Indonesia. Data yang telah di peroleh di analisis dengan menggunakan program Microsoft Office Exel 2007 dan Statistical Program for Social Science Versi IBM SPSS Statistic 20.

\section{HASIL DAN PEMBAHASAN}

\section{Persepsi Mahasiswa Mengenai Pentingnya Pendidikan Gizi dalam Mencegah}

\section{Kecenderungan Eating Disorder pada Atlet}

Performance atlet sangat dipengaruhi oleh stamina mereka. Untuk mendukung stamina yang prima, mereka harus mendapatkan asupan gizi yang baik melalui pemilihan makanan yang baik. beberapa penelitian mengungkapkan bahwa atlet yang memiliki pengetahuan gizi yang bagus, berpengaruh terhadap perilaku makan yang mereka jalankan. Pengetahuan gizi yang baik dapat mempengaruhi perilaku gizi seorang Atlet. Azizi et al (2010) mengungkapkan bahwa pengetahuan gizi seorang Atlet di Iran berkorelasi positif dan signifikan terhadap perilaku gizi seorang Atlet laki-laki dan Atlet perempuan dengan koefisien korelasi masing-masing $\mathrm{r}=0.424, \mathrm{p} \leq 0.01$ dan $\mathrm{r}=0.422, \mathrm{p} \leq 0.0$. Tabel berikut ini menjelaskan persepsi responden mengenai pentingnya pendidikan gizi dalam mendukung performance Atlet.

Tabel 1. Persepsi Responden mengenai pentingnya pendidikan gizi

\begin{tabular}{lcc}
\hline \multicolumn{1}{c}{ Persepsi } & $\mathrm{n}$ & $\%$ \\
\hline Tidak Penting & 0 & 0 \\
Cukup penting & 3 & 4,1 \\
Penting & 6 & 8,2 \\
Sangat penting & 64 & 87,7 \\
\hline Total & 73 & 100 \\
\hline
\end{tabular}

Berdasarkan Tabel 1, lebih dari setengah responden (87,7\%) mempunyai persepsi bahwa pendidikan gizi sangat penting dalam menunjang performance seorang atlet. sedangnya sebagian kecil masing-masing 8,2\% mempunyai persepsi bahwa pendidikan gizi penting untuk menunjang performance atlet. dan sisanya sebanyal $4,1 \%$ mempunyai persepsi bahwa pendidikan gizi cukup penting dalam menunjang performance seorang Atlet. Pendidikan gizi merupakan suatu 
gabungan berbagai hal beragam strategi pendidikan yang disertai dukungan lingkungan, terancang untuk memfasilitasi adopsi keilmuan terkait pemilihan makanan dan bahan pangan yang disadari oleh adopter secara sukarela dikaitkan dengan perilaku dalam meningkatkan kesehatan mulai pada tahap individu, institusional, masyarakat dan level pengambil kebijakan.

Responden merupakan seorang Atlet sekaligus mahasiswa Program Studi Pendidikan Kepelatihan Olahraga,FPOK, UPI selain di siapkan untuk jadi guru, mereka juga di siapkan untuk menjadi seorang pelatih profesional di sekolah dan di luar sekolah dalam bidang olahraga. sebagi seorang pelatih dan calon guru olahraga tentu saja mereka harus mengerti mengenai gizi yang sangat di perlukan oleh setiap orang, baik itu anak didik maupun para Atlet. Sebab seorang pelatih merupakan sumber informasi bagi para Atletnya, termasuk dalam hal pemilihan makanan yang erat kaitannya dengan gizi. Hasil penelitian Burns, et al (2004) menemukan bahwa, pelatih merupakan sumber informasi utama para atlet dalam mendapatkan informasi mengenai gizi. Penelitian lain yang di lakukan oleh Jacobson (2001) dalam grete et al (2011) mengemukakan bahwa dari 330 responden penelitian, $22 \%$ responden mengemukakan bahwa pelatih merupakan sumber informasi utama dalam mendapatkan pengetahuan tentang gizi.

\section{Persepsi Responden mengenai Tempat yang tepat dalam penyampaian Pendidikan Gizi bagi Atlet}

Pendidikan gizi dapat di lakukan dalam tiga ranah pendidikan, yaitu Pendidikan Formal, Pendidikan yang benar-benar dilembagakan, mempunyai tingkatan yang berurutan serta tersusun secara hirearkis mulai pendidikan dasar sampai perguruan tinggi. Pendidikan Informal Pendidikan yang diperoleh seorang individu dari pengalaman hidup sehari-hari serta berlangsung terus sepanjang hidupnya. Serta Pendidikan non Formal Sistem pendidikan diluar pendidikan formal yang diselenggarakan berdasarkan kebutuhan masyarakat. Tabel berikut ini menjelaskan persepsi responden mengenai tempat yang tepat dalam penyampaian pendidikan gizi bagi Atlet. 
Tabel 2. Persepsi Responden mengenai Tempat Penyampaian Pendidikan Gizi bagi Atlet

\begin{tabular}{lcc}
\hline \multicolumn{1}{c}{ Tempat } & $\mathrm{N}$ & $\%$ \\
\hline Rumah & 12 & 16,4 \\
Club Olahraga & 3 & 4,1 \\
Kampus & 0 & 0 \\
Kampus dan Club Olahraga & 58 & 79,5 \\
\hline Total & 73 & 100 \\
\hline
\end{tabular}

Berdasarkan tabel dua diatas lebih dari setengah responden $(79,5 \%)$ mempunyai persepsi bahwa tempat yang paling tepat untuk menyampaikan pendidikan gizi bagi para atlet adalah di Kampus dan Club olahraga yang diikuti oleh para Atlet. sedangkan sebagian kecil responden $(16,4 \%)$ memilih rumah sebagai tempat yang tepat dalam menyampaikan pendidikan gizi. Sisanya sebanyak 4,1\% memilih Club olahraga sebagai tempat untuk penyampaian pendidikan gizi bagi Atlet. Responden penelitian memilih Kampus dan club olahraga untuk penyampaian pendidikan gizi untuk Atlet karena mereka merupakan mahasiswa, sehingga menurut para responden akan lebih efektif jika penyampaian pendidikan gizi untuk Atlet di lakukan di Kampus yang terintegrasi dengan mata kuliah dan juga di club olahraga, karena club olahraga merupakan tempat mereka berkumpul dan bertukar informasi, sehingga merupakan tempat yang strategis juga untuk menyampaikan pendidikan gizi. Hasil penelitian Grete et al (2011) terhadap mahasiswa yang juga Atlet Sofball di Amerika mendapatkan hasil bahwa $31 \%$ responden mendapatkan pendidikan mengenai gizi dari perkuliahan.

\section{Persepsi Responden Mengenai Bentuk Kegiatan dalam Penyampaian Pendidikan Gizi bagi Atlet}

Pendidikan gizi dapat di lakukan dalam bentuk kegiatan yang beragam. mulai dari bentuk penyuluhan gizi, pelatihan, bentuk pendidikan formal seperti di tingkat SD,SMP,SMU dan perkuliahan di pendidikan tinggi. Selain itu bentuk kegiatan tidak hanya dilakukan secara tatap muka, tetapi juga dalam bentuk Video Tutorial maupun tutorial Online. Tabel berikut ini menjelaskan persepsi 
responden mengenai Bentuk kegiatan dalam penyampaian pendidikan gizi bagi Atlet.

Tabel 3.Persepsi Responden mengenai Bentuk Kegiatan Penyampaian Pendidikan Gizi bagi Atlet

\begin{tabular}{lcc}
\hline \multicolumn{1}{c}{ Bentuk Kegiatan } & $\mathrm{n}$ & $\%$ \\
\hline Perkuliahan & 10 & 13,7 \\
Pelatihan sewaktu-waktu & 5 & 6,8 \\
Penyuluhan secara berkala & 42 & 57,5 \\
Konseling & 12 & 16,4 \\
Bentuk lain & 4 & 5,5 \\
\hline Total & 73 & 100 \\
\hline
\end{tabular}

Berdasarkan Tabel 3, lebih dari setengah responden (57,5\%) mempunyai persepsi bahwa bentuk kegiatan yang paling tepat dalam menyampaikan pendidikan gizi bagi Atlet adalah penyuluhan secara berkala. sedangkan sisanya sebanyak 16,4\% mempunyai persepsi bahwa konseling merupakan bentuk kegiatan yang tepat. 13,7\% mempunyai persepsi bahwa perkuliahan merupakan bentuk kegiatan yang tepat. Persentase terkecil $(6,8 \%)$ mempunyai persepsi bahwa pelatihan sewaktu-waktu merupakan bentuk kegiatan yang dapat di gunakan dalam penyampaian materi mengenai pendidikan gizi bagi Atlet. Bentuk Penyuluhan gizi secara berkala dapat di gunakan untuk menyampaikan materi mengenai gizi kepada para Atlet dan terbukti efektif dalam meningkatkan pengetahuan gizi para Atlet, hal ini sesuai dengan penelitian yang di lakukan oleh di Doris et al (2004) terhadap para Atlet perempuan yaitu Atlet renang dan sepak bola yang di beri intevensi mengenai pendidikan gizi dan meningkatkan tingkat kepercayaan diri. Hasil penelitian menunjukkan bahwa intervensi pendidikan gizi dapat meningkatkan pengetahuan gizi, perubahan perilaku makan yang positif serta tingkat kepercayaan diri para Atlet perempuan tersebut.

\section{Persepsi Responden mengenai Metode mengajar yang tepat digunakan dalam penyampaian Pendidikan Gizi bagi Atlet}

Metode mengajar sangat berpengaruh terhadap hasil belajar peserta didik. Suhardjo (2003) mengungkapkan bahwa dalam menyampaikan pendidikan gizi pada orang dewasa tidak ada satu metode yang dianggap paling tepat karena 
setiap metode mmempunyai kelebihan dan kekurangan sehingga diperlukan kolaborasi dari beberapa metode untuk menghasilkan pembelajaran gizi yang berhasil. Tabel berikut ini menjelaskan persepsi responden mengani jenis metode yang paling tepat digunakan dalam menyampaikan pendidikan gizi bagi Atlet.

Tabel 4.Persepsi Responden mengenai Metode mengajar dalam Penyampaian Pendidikan Gizi bagi Atlet

\begin{tabular}{lcc}
\hline \multicolumn{1}{c}{ Metode mengajar } & $\mathrm{n}$ & $\%$ \\
\hline Ceramah & 4 & 5,5 \\
Diskusi & 17 & 23,3 \\
Ceramah,diskusi dan demonstrasi & 18 & 24,7 \\
Diskusi, Demontrasi, Role playing & 32 & 43,8 \\
Metode lain & 2 & 2,7 \\
\hline Total & 73 & 100 \\
\hline
\end{tabular}

Berdasarkan Tabel 4, hampir setengah responden (43,8\%) mempunyai persepsi bahwa metode yang paling tepat di gunakan untuk penyampaian materi gizi bagi para Atlet adalah gabungan dari metode diskusi, demontrasi dan simulasi. $24,7 \%$ responden mempunyai persepsi bahwa metode yang tepat adalah gabungan dari metode ceramah, diskusi dan demontrasi. 23,3\% mempunyai persepsi bahwa metode diskusi yang tepat, sedangkan 5,5\% berpersepsi bahwa metode ceramah yang paling tepat,sedangkan sisanya sebesar $2,7 \%$ mempunyai persepsi bahwa metode lain seperti bercerita paling tepat di gunakan untuk penyampaian materi gizi.

Suhardjo (2003) mengemukakan bahwa metode diskusi sangat cocok digunakan untuk menggali pendapat peserta tentang informasi yang akan di sampaikan. Dalam diskusi para peserta dapat mengemukakan pendapatnya masing-masing dan akan lebih mudah mengubah pendapatnya karena mendengar pendapat dari orang lain yang di anggap lebih baik.

Metode Role playing dalam pendidikan gizi memiliki beberapa keuntungan, seperti yang dikemukan oleh Suhardjo (2003), yaitu :

1)Peserta melatih diri dalama keadaan dilindungi sambil belajar menerima nasihat dan kritik baik dari fasilitator maupun sesame peserta, 2) peserta akan melatih kepercayaan diri sendiri dan merasakan bagaimana mengalami tekanan-tekanan. 3) menimbulkan partisipasi dari peserta dan menyebabkan suasana lebih hidup dan menarik. 4) peserta dapat mencoba keterampilan dan pengetahuan yang 
diperolehnya terutama di bidang antar manusia, sekaligus dapat menemukan kekurangan-kekurangan untuk kemudia secara sadar di perbaiki.

\section{Persepsi Responden Mengenai Durasi waktu dalam penyampaian pendidikan gizi}

Lamanya waktu dalam menyampaikan satu materi akan berpengaruh pada tingkat konsentrasi peserta didik. waktu yang terlalu lama akan menyebabkan peserta didik bosan, begitupun sebaliknya, apabila waktu yang digunakan terlalu pendek maka di khawatirkan pesan atau tujuan pembelajaran tidak akan tersampaikan secara utuh. Tabel berikut menjelaskan persepsi responden mengenai durasi atau waktu yang paling tepat dalam penyampaian materi pendidikan gizi

Tabel 5.Persepsi Responden mengenai Durasi/ waktu Penyampaian Pendidikan Gizi bagi Atlet

\begin{tabular}{lcc}
\hline \multicolumn{1}{c}{ Durasi waktu } & $\mathrm{n}$ & $\%$ \\
\hline 30 menit & 14 & 19,2 \\
60 menit & 39 & 53,4 \\
90 menit & 20 & 27,4 \\
120 menit & 0 & 0 \\
\hline Total & 73 & 100 \\
\hline
\end{tabular}

Berdasarkan Tabel 5, lebih dari setengah responden $(53,4 \%)$ mempunyai persepsi bahwa waktu atau durasi yang paling tepat dalam menyampaikan pendidikan gizi bagi Atlet adalah 60 menit. Sedangkan 27,4\% mengemukakan bahwa durasi waktu yang tepat adalah 90 menit dan sisanya sebanyak 19,2\% mengemukakan bahwa waktu 30 menit sangat tepat di gunakan untuk menyampaikan materi mengenai pendidikan gizi untuk Atlet.

\section{Persepsi Responden Mengenai Media dalam Penyampaian Pendidikan Gizi bagi Atlet}

Media Pembelajaran merupakan suatu alat yang dapat membantu pendidik dalam menyampaikan materi. Menurut Suhardjo (2003) beberapa media yang dapat digunakan dalam menyampaikan pendidikan gizi diantaranya yaitu : Media gambar seperti poster, poster terbuka, pawai foto, flexiflan, kartu permainan. media suara dan media cetak. Tabel berikut ini menjelaskan mengenai persepsi 
responden mengenai jenis media yang paling tepat dalam menyampaikan pendidikan gizi bagi para Atlet.

Tabel 6.Persepsi Responden mengenai Media dalam Penyampaian Pendidikan Gizi bagi Atlet

\begin{tabular}{lcc}
\hline \multicolumn{1}{c}{ Jenis media } & $\mathrm{n}$ & $\%$ \\
\hline Media Audio Visual & 38 & 52,1 \\
Media nyata & 29 & 39,7 \\
Media cetak & 6 & 8,2 \\
\hline Total & 73 & 100 \\
\hline
\end{tabular}

Berdasarkan Tabel 6, lebih dari setengah responden (52,1\%) mempunyai persepsi bahwa media yang paling tepat digunakan untuk menyampaikan pendidikan gizi bagi Atlet adalah media audio visual seperti media Power point. kurang dari setengah responden $(39,7 \%)$ mempunyai persepsi bahwa media nyata berupa contoh porsi makanan dan macam-macam makanan merupakan media yang paling tepat dalam menyampaikan pendidikan gizi. sedangkan sisanya sebanyak 8,2\% berpersepsi bahwa media cetak seperti leaflet sangat tepat digunakan untuk menyampaikan pendidikan gizi. hasil penelitian yang dilakukan di Amerika oleh Williamsburg-James City County School dalam (Schindler, 2010) merupakan salah satu program kesehatan sekolah yang menitik beratkan pada pengenalan terhadap berbagai sayuran dan buah-buahan serta berbagai aktivitas fisik yang dapat mencegah obesitas pada anak-anak. Program ini menggunakan berbagai jenis media seperti poster dan berbagai permainan. Hasil penelitian menunjukkan bahwa siswa yang mengikuti program School Health Initiative Program (SHIP) meningkat pengetahuan tentang makanan sehat dan mereka juga mau mencoba berbagai makanan yang bergizi seperti sayuran dan buah-buahan dibandingkan dengan siswa yang tidak mengikuti program tersebut.

\section{KESIMPULAN}

Hasil penelitian menunjukkan bahwa responden mempunyai persepsi kuat bahwa pendidikan gizi sangat penting dalam mencegah kecenderungan Eating Disorder pada atlet. Sebagian besar responden setuju bahwa tempat yang paling tepat untuk menyampaikan pendidikan gizi bagi para atlet adalah di kampus dan klub olahraga. Setengah dari responden memberikan persepsi bahwa bentuk 
kegiatan yang paling tepat dalam menyampaikan pendidikan gizi bagi atlet adalah penyuluhan secara berkala, dengan menggunakan metode gabungan dari diskusi, demontrasi dan simulasi, dan durasi yang dianggap tepat selama 60 menit, serta media yg tepat adalah audio visual.

\section{DAFTAR PUSTAKA}

Azizi Mohammad, Farhad Rahmani-Nia, Maryam Malaee, Mina Malaee, Narges, Khosravi. (2010) a study of nutritional knowledge and attitudes of elite college athletes in iran. Brazilian Journal of Biomotricity, v. 4, n. 2, p. 105112, 2010 (ISSN 1981-6324).

Borgen, Jorunn Sundgot \& Monica Klungland Torstveit. (2004), Prevalence of Eating Disorders in Elite Athletes Is Higher Than in the General Population, Clin J Sport Med • Volume 14, Number 1, January 2004.

Burns, R. D. M. R. Schiller, M. A. Merrick and K. N. Wolf (2004) Intercollegiate Student Athlete Use of Nutritional Supplements and the Role of Athletic Trainers and Dietitians in Nutrition Counseling.

Doris A. Abood, David R. Black, Rachel D. Birnbaum.(2004) Nutrition Education Intervention for College Female . Abstract. Terhubung berkala http://www.sciencedirect.com/science/journal/14994046/36/3

Grete R. Hornstrom, Carol A. Friesen, Jane E. Ellery, Kimberli Pike (2011) Nutrition Knowledge, Practices, Attitudes, and Information Sources of MidAmerican Conference College Softball Players Food and Nutrition Sciences, 2011, 2, 109-117

Penggalih, Mirza Hapsari Sakti Titis, Emy Huriyati (2007). Gaya hidup, status gizi dan stamina atlet Pada sebuah klub sepakbolaberita Kedokteran Masyarakat, Vol. 23, No. 4, Desember 2007.

Saputri, Gita Ayu Rosalinda Ratu \& Fillah Fithra Dieny. (2012). Female Athlete Triad Pada Atlete Putri di Pusat Pendidikan Latihan (PUSDIKLAT) Ragunan Jakarta. Journal of Nutrition College, volume 1. No.1. 2012 (283298).

Schindler.Jenifer (2010) The Effect of Nutrition Education on Children's Healthy Food Choices.

Suhardjo (2003), Berbagai cara pendidikan gizi, Jakarta, Bumi Aksara 